\title{
O ENSINO DE GEOGRAFIA NA PERSPECTIVA DA EDUCAÇÃO INCLUSIVA NO INSTITUTO FEDERAL DO TRIÂNGULO MINEIRO - CAMPUS PATROCÍNIO- $M G$
}

\author{
Patrícia Rosa Aguiar ${ }^{1}$ \\ Francisco Wendell Dias Costa²
}

Resumo: O objetivo geral é compreender o processo de ensino-aprendizagem da disciplina Geografia, voltado para uma estudante que apresenta deficiência visual com necessidade educacional específica, por meio da utilização de tecnologias assistivas, no Instituto Federal do Triângulo Mineiro, Campus Patrocínio - MG. O foco metodológico da pesquisa está pautado na fenomenologia, na observação situada, na abordagem qualitativa descritiva, bem como a aplicação de procedimentos metodológicos. Os resultados evidenciaram que a confecção de materiais didáticos foi destinada para facilitar e potencializar o ensino-aprendizagem de uma aluna com deficiência visual, e promover a inclusão das tecnologias assistivas na educação geográfica. Para tanto, foram produzidos mapas táteis e maquetes das placas tectônicas, biomas e formações vegetais e circulação geral da atmosfera, visando estimular a percepção integrada da paisagem. A confecção dos mapas passa pela conversão/aquisição em meio digital e sua impressão em papel tamanho $A 3$, com alto relevo produzido com a utilização de materiais como tinta, barbante, cola, grãos etc. Portanto, a utilização de mapas táteis, de maquetes, experimentos, que se compõem as tecnologias assistivas, proporcionam melhor qualidade no processo de ensinoaprendizagem da Geografia, sobretudo, na perspectiva da educação inclusiva e na inclusão de pessoas com deficiência visual.

Palavras-chave: Educação inclusiva; Tecnologias assistivas; Ensino de geografia.

\section{GEOGRAPHY TEACHING FROM AN INCLUSIVE EDUCATION PERSPECTIVE AT THE FEDERAL INSTITUTE OF TRIÂNGULO MINEIRO, ON THE PATROCÍNIO CAMPUS, BRAZIL}

\begin{abstract}
In the scope of specific educational needs of a student with visual impairment, this paper aims to understand the geography teaching-learning process supported by assistive technology, at the Federal Institute of Triângulo Mineiro, on the Patrocínio campus, state of Minas Gerais (MG), Brazil. The method of this study comprised mainly phenomenology, on-site observation, and the qualitative descriptive approach, in addition to the use of methodological procedures. The results showed that the educational materials prepared for the visually impaired student aimed to facilitate and improve her geography learning process by resorting to assistive

\footnotetext{
${ }^{1}$ Doutoranda em Geografia. Professora de Geografia do Instituto Federal do Triângulo Mineiro (MG).

${ }^{2}$ Doutor em Geografia. Professor de Geografia do Instituto Federal de Educação, Ciência e Tecnologia do Maranhão, Campus Barra do Corda (MA).
} 
technology. To that end, tactile maps, and models of tectonic plates, biomes, vegetal formations, and general circulation of the atmosphere were built in order to stimulate an integrated perception of landscape. The preparation of the maps involves digital conversion and then printing on paper size A3, followed by an embossed effect produced using materials such as ink, string, glue, grains etc. Therefore, the use of such tactile maps, models and experiments typical of assistive technology effectively improve the teaching-learning process of geography, especially from an inclusive education perspective and for the inclusion of visually impaired students.

Keywords: Inclusive Education; Assistive Technology; Geography Teaching.

\section{INTRODUÇÃO}

Por muito tempo perdurou, entre os especialistas, o entendimento de que a educação especial organizada, de forma paralela à educação comum, seria mais apropriada para a aprendizagem dos alunos que apresentassem alguma deficiência, física ou mental, problemas de saúde, ou qualquer inadequação com relação à estrutura organizada pelos sistemas de ensino. Essa concepção exerceu impacto duradouro na história da educação especial, resultando em práticas que enfatizavam os aspectos relacionados à deficiência, em contraposição à dimensão pedagógica.

A educação especial é uma modalidade de ensino que deve perpassar todos os níveis, etapas e modalidades. Para a construção de sistemas educacionais inclusivos, a organização de escolas e classes especiais passaram a ser repensadas, com mudança estrutural e cultural das escolas para que todos os estudantes tenham suas especificidades educacionais atendidas. As instituições educacionais devem disponibilizar serviços e recursos próprios, a fim de orientar alunos e professores quanto ao atendimento educacional especializado e articulado nas turmas do ensino regular (BRASIL, 1996).

Na perspectiva da educação inclusiva, a educação especial passa a constituir uma proposta pedagógica do sistema de ensino, definindo como seu público-alvo os alunos com deficiência, transtornos globais de desenvolvimento e altas habilidades/superdotação, orientando para 0 atendimento às necessidades educacionais especiais desses alunos. Nesse sentido, os componentes curriculares tiveram que se adequar às diretrizes da educação inclusiva.

Alguns desafios para a efetiva inclusão escolar de pessoas com necessidades educativas específicas são: a falta de preparo do professor, a existência de currículos tradicionais e inadequados e a ausência de materiais adequados para facilitar o ensino-aprendizado. Dessa forma, a temática desenvolvida neste trabalho tem como justificativa, a discussão referente à inclusão escolar de alunos com necessidades específicas no Instituto Federal do Triângulo Mineiro (IFTM), a qualificação dos docentes e a disponibilidade de tecnologias assistivas para o atendimento desses discentes.

Este trabalho apresenta uma atividade prática na disciplina Geografia, a partir da exposição de práticas educativas utilizadas para o ensino de Geografia ofertado a uma estudante com cegueira, do curso Técnico em Administração, integrado ao Ensino Médio do Instituto Federal do Triângulo Mineiro (IFTM), Campus PatrocínioMG. De modo contextualizado e com um aporte teórico e normativo, a presente pesquisa apresenta as considerações e impressões que essa vivência trouxe, visando contribuir para o ensino inclusivo de Geografia. 
As dúvidas quanto aos procedimentos a serem adotados em sala de aula, a falta de formação para atuação na educação especial e a expectativa em receber a estudante, acabaram definindo duas questões norteadoras a partir daquele momento: i) Como se dá o processo de ensino-aprendizagem de Geografia referente aos estudantes com cegueira, matriculados em turmas regulares da educação básica e profissional? ii) Qual tem sido o apoio (materiais didático-pedagógicos, capacitação, pesquisa) dado aos professores que têm em suas turmas estudantes com cegueira?

Este trabalho tem como objetivo geral compreender o processo de ensinoaprendizagem da disciplina Geografia, voltado para uma estudante que apresenta deficiência visual com necessidade educacional específica, por meio da utilização de tecnologias assistivas, no IFTM, Campus Patrocínio - MG. Tem como objetivos específicos: i) analisar as normativas que compõem a política educacional inclusiva no Brasil e o ensino da Geografia e ii) acompanhar e avaliar a produção do material didático/avaliativo e sua aplicabilidade na disciplina Geografia, na perspectiva inclusiva.

\section{METODOLOGIA}

Como instrumento para possibilitar a apreensão da realidade, esta pesquisa foi desenvolvida com foco metodológico na fenomenologia, na observação situada e na abordagem qualitativa descritiva, bem como aplicação de procedimentos metodológicos.

Lencioni (2004) afirma que a fenomenologia constitui uma corrente filosófica que considera os objetos como fenômenos que devem ser analisados da maneira que aparecem na consciência do pesquisador. Prioriza a percepção e entende que qualquer ideia prévia que se tem sobre a natureza dos objetos deve ser abolida, pois pode provocar interferências durante a pesquisa.

Triviños (1987) enfatiza que o observador elabora os significados e interpretações dos fenômenos sociais, descobrindo as características culturais que envolvem a existência dos participantes da pesquisa, entendendo a realidade social como uma construção humana. Esse método deu embasamento na sistematização dos processos de observação e explicação dos fatos observados.

A observação situada, proposta por Geertz (2008), permite ao pesquisador apreender os significados que os próprios sujeitos da pesquisa dão aos seus processos. Essa perspectiva pretende não falar pelos "sujeitos-alvo", mas favorecer um diálogo entre sujeitos pesquisados e sujeito pesquisador. Nesse sentido,

o que procuramos, no sentido mais amplo do termo, que compreende muito mais do que simplesmente falar, é conversar com eles. O que é muito mais difícil, e não apenas com estranhos, do que se reconhece habitualmente (GEERTZ, 2008, p. 10).

Essa estratégia metodológica deu subsídio para a participação nos eventos ocorridos durante a pesquisa, e para observar de forma situada, evitando fazer julgamentos de valor sobre a ação em observação, faz-se necessário, portanto, o desenvolvimento do ensino-aprendizagem a partir do auxílio das tecnologias assistivas.

A abordagem qualitativa descritiva possibilitou o embasamento teórico para a interpretação dos dados obtidos, a realização de entrevistas, o aprendizado da 
discente com portadora de deficiência visual e o entendimento das estratégias metodológicas utilizadas para o alcance dos objetivos.

As atividades desenvolvidas na disciplina Geografia, apresentadas neste trabalho, trazem as motivações e metodologias para as ações empreendidas nas situações de ensino-aprendizagem, as considerações e impressões que a vivência docente proporcionou.

O apoio técnico-instrumental de um profissional especializado em Braille foi fundamental para o desenvolvimento da pesquisa, pois ofereceu suporte necessário para o alcance dos objetivos traçados e complementação da metodologia. Para tanto, foram utilizados os seguintes procedimentos:

- Levantamento e revisão bibliográfica da temática em estudo, incluídos os marcos históricos, informações do Censo Escolar e normativas específicas que compõem a Política Nacional de Inclusão;

- Seleção das temáticas de estudo em Geografia, levantadas a partir do currículo do curso Técnico em Administração integrado ao Ensino Médio, a fim de identificar os conteúdos que necessitariam da confecção de materiais didáticos adaptados para atendimento da aluna com necessidades específicas;

- Produção de materiais didáticos direcionados à aluna portadora com necessidade especial e realização das atividades avaliativas pelos estudantes, bem como a aplicação de tecnologias assistivas que compõem o processo de ensinoaprendizagem da Geografia;

- A confecção de materiais didáticos adaptados para o ensino de Geografia realizada pela professora de apoio especializado, contratada pela instituição, que também efetuou a transcrição de provas, trabalhos e demais atendimentos à aluna em questão. O preparo do material didático era solicitado por cada docente interessado, o qual informava a temática a ser trabalhada em sala de aula, a finalidade do material e as devidas adaptações a serem feitas;

- Os principais recursos utilizados foram: papelão, barbante, EVA (Etil Vinil Acetato), cola de isopor, cola tridimensional, biscuit, isopor, papéis diversos, lixa, algodão, materiais recicláveis, grãos, tecidos, entre outros materiais de texturas diferentes;

- Avaliação da aplicabilidade das tecnologias assistivas em sala de aula;

- Realização de entrevista semiestruturada com a aluna com deficiência visual e com a profissional de apoio especializado em Braille;

- Registro fotográfico.

\section{A POLÍTICA EDUCACIONAL INCLUSIVA NO BRASIL E O ENSINO INCLUSIVO DA GEOGRAFIA}

A educação especial pode ser estruturada, através do seu histórico, em 4 fases: a primeira, assistencialista, com prioridade no bem-estar da pessoa com deficiência; a segunda, com prioridade no atendimento médico-hospitalar e psicológico; a terceira priorizou a integração da educação especial no sistema de ensino (paradigma da integração, que durou em torno de 40 anos (1949-1989)), e a quarta, introduziu a inclusão escolar no ensino regular (a partir do início da década de 1990) (RODRIGUES, 2017).

Historicamente, a exclusão educacional impedia o ingresso de pessoas com deficiência ou com necessidades específicas em classes comuns do ensino regular. $A$ infraestrutura instalada, o despreparo dos profissionais de ensino, o currículo dos cursos de licenciatura, o pouco material didático adaptado, a metodologia utilizada, e 
até mesmo o processo seletivo do aluno, dentre outros fatores, favoreciam a exclusão social desse público-alvo, buscando assim, atendimento nas escolas especializadas.

A organização da educação especial, fundamentada no conceito de normalidade/anormalidade, sugere formas de atendimento clínico terapêutico fortemente ancoradas nos testes psicométricos que definem, por meio de diagnósticos, as práticas escolares para os alunos com deficiência. Diante disso, surge a proposta de desenvolver educação inclusiva para alunos portadores de necessidades especiais, incluindo-os em salas regulares de ensino.

Nessa perspectiva, a inclusão pode ser definida, como

O processo pelo qual os sistemas sociais comuns são tornados adequados para toda a diversidade humana - composta por etnia, raça, língua, nacionalidade, gênero, orientação sexual, deficiência e outros atributos - com a participação das próprias pessoas na formulação e execução dessas adequações (SASSAKI, 2009, p. 1).

A educação inclusiva entende a instituição escolar como um espaço que deve ser acessível a todos e onde os estudantes, a partir das suas diferenças, participem ativamente do processo de construção do conhecimento, de acordo com as suas capacidades e necessidades específicas, oportunizando o seu desenvolvimento como cidadãos (RODRIGUES, 2017).

Ropoli et al. (2010) e Rodrigues (2017) relatam que proporcionar um ensino de qualidade por meio da educação inclusiva é uma tarefa que deve ser assumida por todos que compõem o sistema educacional - professores, gestores, especialistas, pais, alunos e demais profissionais - a partir de uma proposta que, apesar de ser comum a todas as escolas, possui as suas peculiaridades.

Ao reconhecer que as dificuldades enfrentadas nos sistemas de ensino evidenciam a necessidade de confrontar as práticas discriminatórias e criar alternativas para superá-las, a educação inclusiva assume espaço central no debate acerca do papel da escola, na sociedade contemporânea e na superação da lógica da exclusão (BRASIL, 2008). A escola atual necessita de mudanças para atender melhor a todos.

Esse desafio é mencionado por ROPOLI et al. (2010, p. 9)

A escola comum se torna inclusiva quando reconhece as diferenças dos alunos diante do processo educativo e busca a participação e o progresso de todos, adotando novas práticas pedagógicas. Não é fácil e imediata a adoção dessas novas práticas, pois elas dependem de mudanças que vão além da escola e da sala de aula. Para que essa escola possa se concretizar, é patente a necessidade de atualização e desenvolvimento de novos conceitos, assim como a redefinição e a aplicação de alternativas e práticas pedagógicas e educacionais compatíveis com a inclusão.

Isso implica em mudanças no atual paradigma educacional. Se o que se pretende é que a educação inclusiva ocorra, de fato, "é urgente que seus planos se redefinam para uma educação voltada para a cidadania global, plena, livre de preconceitos e que reconhece e valoriza as diferenças" (MANTOAN, 2003, p. 13). Na Constituição da República Federativa do Brasil, de 1988, os direitos das pessoas com deficiência são mencionados em diversos artigos, dentre os quais podemos destacar aqueles relacionados à educação: 
Art. 205 - A educação, direito de todos e dever do Estado e da família, será promovida e incentivada com a colaboração da sociedade, visando ao pleno desenvolvimento da pessoa, seu preparo para o exercício da cidadania e sua qualificação para o trabalho.

Art. 206 - O ensino será ministrado com base nos seguintes princípios: Inciso I: Igualdade de condições de acesso e permanência na escola, como um dos princípios para o ensino; (...).

Art. 208 - O dever do Estado com a educação será efetivado mediante a garantia de:

(...) Inciso III: atendimento educacional especializado aos portadores de deficiência, preferencialmente na rede regular de ensino (BRASIL, 1988, p. 71).

No Estatuto da Criança e do Adolescente - ECA, Lei n. ${ }^{\circ} 8.069 / 90^{3}$, traz o Art. 55 com a afirmação que os pais ou responsável têm a obrigação de matricular seus filhos ou pupilos na rede regular de ensino. Trata-se, portanto, de uma educação destinada a todos, fundamentada no direito constitucional, sem discriminação. Assim, - Estado deve articular meios para alcançar a inclusão social na educação, a partir dos marcos normativos educacionais brasileiros, dos acordos e tratados internacionais, dos quais o Brasil é signatário.

Essas diretrizes visam garantir o atendimento educacional especializado às crianças com deficiência (preferencialmente na rede regular de ensino), assegurar o trabalho protegido ao adolescente com deficiência e a prioridade de atendimento nas ações e aplicabilidade de políticas públicas de prevenção e proteção para famílias com crianças e adolescentes nessa condição.

A Declaração de Salamanca elaborada na Conferência Mundial sobre Educação Especial, realizada em Salamanca, na Espanha, em 1994, tem como objetivo, disponibilizar diretrizes básicas para a formulação e reforma de políticas e sistemas educacionais, de acordo com o movimento de inclusão social. Ela passou a inspirar a formulação das políticas públicas da educação inclusiva, convertendo-se em um dos principais documentos mundiais acerca da temática em questão.

Foi por meio dessa declaração, que o conceito de necessidades educacionais especiais passa a ser amplamente disseminado e ressaltou a interação das características individuais dos alunos com o ambiente educacional e social, chamando a atenção do ensino regular para o desafio de atender as diferenças e promover a inclusão educacional (BRASIL, 1994).

Dentre as Diretrizes para a ação em nível nacional, quanto a política e organização, destaca-se o item 19, indicando que a educação inclusiva é aquela em que as crianças com necessidades educativas especiais devem ser incluídas nas escolas de ensino regular, indicando que,

A colocação de crianças com deficiência nas classes regulares deve constituir parte integrante dos planos nacionais que visam a educação para todos. Mesmo nos casos excepcionais, em que as crianças são postas em escolas especiais, a sua educação não deve ser inteiramente segregada, encorajando-se a frequência de escolas regulares a meio tempo (BRASIL, 1994).

A Política Nacional de Educação Especial (PNEE), criada em 1994, destacou as modalidades de atendimento em educação especial no Brasil: atendimento

\footnotetext{
${ }^{3}$ Disponível em: http://www.planalto.gov.br/ccivil_03/leis/18069.htm. Acesso em: 02 de fev. 2019.
} 
domiciliar, classe comum, classe especial, classe hospitalar, centro integrado de educação especial, ensino com professor itinerante, escola especial, oficina pedagógica, sala de estimulação essencial e sala de recursos (BRASIL, 1994).

A educação especial se organizou como atendimento educacional especializado substitutivo ao ensino comum, evidenciando diferentes compreensões, terminologias e modalidades que levaram à criação de instituições especializadas, escolas especiais e classes especiais (RODRIGUES, 2017). A inclusão escolar nas classes regulares de ensino apresentou o "processo de integração instrucional", possibilitando que alunos com algum tipo de deficiência tenham condições de acompanhar e desenvolver as atividades curriculares programadas do ensino comum.

A Lei de Diretrizes e Bases da Educação Nacional (LDBEN) foi promulgada pela Lei n. $^{\circ}$ 9.394/1996, e trouxe um capítulo específico para a Educação Especial (Capítulo V), abordada nos artigos 58, 59 e 60. A oferta de educação especial deve ter início na educação infantil, oferecida, preferencialmente, na rede regular de ensino, e quando não for possível a integração do estudante nas classes comuns de ensino regular, o atendimento educacional deverá ser feito em classes, escolas ou serviços especializados (BRASIL, 1996).

Ademais, o texto enfatiza que os sistemas de ensino assegurarão currículos, métodos, técnicas, recursos educativos e organização específicos, para atender às necessidades dos estudantes com deficiência, transtornos globais do desenvolvimento e altas habilidades ou superdotação; assim como professores com especialização adequada em nível médio ou superior, para atendimento especializado, além de professores do ensino regular capacitados para a integração desses educandos nas classes comuns (BRASIL, 1996).

Em 2002, foi promulgada a Lei n. ${ }^{\circ} 10.436$, que reconhece a Língua Brasileira de Sinais - Libras - como meio legal de comunicação e expressão. Trata-se de um marco normativo importante para garantir o ensino satisfatório das pessoas com deficiência auditiva, uma vez que exige a presença de um intérprete como garantia de acessibilidade (BRASIL, 2002). O Art. $4^{\circ}$ destaca que

o sistema educacional federal e os sistemas educacionais estaduais, municipais e do Distrito Federal devem garantir a inclusão nos cursos de formação de Educação Especial, de Fonoaudiologia e de Magistério, em seus níveis médio e superior, do ensino da Língua Brasileira de Sinais - Libras, como parte integrante dos Parâmetros Curriculares Nacionais - PCNs, conforme legislação vigente (BRASIL, 2002, p. 1).

Nesse dispositivo legal foram incluídas a presença de um intérprete em sala de aula e a inserção de disciplinas curriculares que envolvam a Libras nos cursos de Licenciatura, Pedagogia e Fonoaudiologia. Atualmente, já existe, também, a formação em Letras com ênfase em Libras para potencializar o processo de ensinoaprendizagem dos portadores de necessidades especiais.

A Política Nacional de Educação Especial na Perspectiva da Educação foi lançada em 2008. Esse documento se insere num contexto de levantamentos e avaliações dos avanços já conquistados, além dos desafios e metas a serem alcançados em conformidade com os princípios educacionais inclusivos (BRASIL, 2008).

Na perspectiva da educação inclusiva, 
a educação especial passa a constituir a proposta pedagógica da escola, definindo como seu público-alvo os alunos com deficiência, transtornos globais de desenvolvimento e altas habilidades/superdotação. Nestes casos e outros, que implicam em transtornos funcionais específicos, a educação especial atua de forma articulada com o ensino comum, orientando para o atendimento às necessidades educacionais especiais desses estudantes. (BRASIL, 2008, p. 8).

A inclusão escolar de alunos com deficiência, Transtorno do Espectro Autista (TEA) e altas habilidades/superdotação, na perspectiva da educação inclusiva, tem como objetivos que merecem destaque, dentre outros: formar professores para o atendimento educacional especializado (AEE) e demais professores para a inclusão; prover acessibilidade arquitetônica nos transportes, nos mobiliários, comunicação e informação e oferecer o AEE (BRASIL, 2008).

O Decreto n. ${ }^{\circ} 7.611$, de novembro de 2011, dispõe sobre o Atendimento Educacional Especializado (AEE) na Educação Básica, definindo-o como o conjunto de atividades, recursos de acessibilidade e pedagógicos organizados institucional e continuamente, prestados na forma complementar ou suplementar à formação dos estudantes (BRASIL, 2011). Enfatiza que o AEE deve integrar a proposta pedagógica da escola, sendo que a União prestará apoio técnico e financeiro aos sistemas públicos de ensino (Estados, Municípios e Distrito Federal), e demais instituições, a fim de ampliar a oferta do atendimento educacional a alunos portadores de necessidades especiais.

Outro marco de destaque é a Lei n. ${ }^{\circ} 13.146$, de 6 de julho de 2015, que instituiu a Lei Brasileira de Inclusão da Pessoa com Deficiência (Estatuto da Pessoa com Deficiência). Essa normativa é destinada a assegurar e a promover, em condições de igualdade, o exercício dos direitos e das liberdades fundamentais por pessoa com deficiência, visando à sua inclusão social e cidadania (BRASIL, 2015). A lei introduz a terminologia Tecnologia Assistiva (TA) ou ajuda técnica, que compõe o objeto de estudo deste trabalho, e refere-se aos

produtos, equipamentos, dispositivos, recursos, metodologias, estratégias, práticas e serviços que objetivem promover a funcionalidade, relacionada à atividade e à participação da pessoa com deficiência ou com mobilidade reduzida, visando à sua autonomia, independência, qualidade de vida e inclusão social (BRASIL, 2015, p. 1).

A TA visa identificar todo o arsenal de recursos e serviços que contribuem para proporcionar ou ampliar habilidades funcionais de pessoas com deficiência e promover vida independente e inclusão. (BERSCH, TONOLLI, 2006). Entretanto, a TA não deve se restringir apenas à produção de artefatos ou materiais didáticos adaptados, mas também à aplicação de serviços, estratégias e práticas para a consolidação do ensino-aprendizagem, valorizando integração e inclusão dos estudantes que necessitam do AEE (RODRIGUES, 2017).

Nessa perspectiva, o professor vai exercer um papel primordial como mediador do conhecimento, por meio da atuação de modo planejado e contextualizado. Vai articular conteúdos e estratégias metodológicas na Geografia, possibilitando ao aluno a construção do seu conhecimento, tornando-o um sujeito ativo nesse processo (SOUZA, 2015; VESENTINI, 2015; ANSELMO, 2015). 
Nesse contexto, a formação dos professores de Geografia ainda não contempla o conhecimento, habilidades e competências necessárias para a inclusão de crianças e jovens com deficiência visual em turmas inclusivas, tornando-se um desafio para os professores ministrarem conteúdos de Geografia a esses estudantes.

Toda criança e jovem já tem consigo os conhecimentos prévios e suas representações sociais do ambiente no qual está inserido. Isso deve ser levado em conta durante a construção do conhecimento, e não é diferente com o estudante com necessidade educacional específica. A percepção do ambiente implica também em compreender os processos que atuam na organização do espaço geográfico (PENA, 1982; TUAN, 2012).

A Geografia, na Educação Básica, procura estudar a relação sociedadenatureza e sua expressão no processo de produção do espaço, nos seus diferentes recortes, como a paisagem, o lugar, o território e a região. Para tanto, é preciso conhecer os diferentes aspectos da superfície terrestre (relevo, solo, vegetação, clima, geologia, população, cultura), inclusive considerando o subsolo e a atmosfera. A visão é utilizada para a observação da paisagem, para a interpretação do espaço, bem como para a construção de gráficos e mapas, enfim, para a construção do conhecimento sobre o espaço geográfico (ALMEIDA, PASSINI, 2010).

A visão é o sentido que nos fornece diversas informações de modo sincrônico, e possibilita, às pessoas que enxergam, a primeira interação e percepção do ambiente. No entanto, os estudantes com deficiência visual (que engloba tanto as pessoas cegas quanto aquelas com baixa visão), fazem uso de outros sentidos (tato, olfato, audição e paladar) para interagir com o ambiente.

A ausência da visão, por exemplo, não incapacita o indivíduo de aprender, mas os métodos criativos tornam-se imprescindíveis na busca de mobilizar os demais sentidos das pessoas com esse tipo de deficiência. É importante ressaltar que o manejo tátil possibilita a aquisição do conhecimento, pois este é resultado de interações, vivências e experiências perceptivas das relações com o ambiente. Nessa perspectiva, Ribeiro (2012, p. 94) ressalta que

O sistema háptico, ou seja, o tato ativo constitui-se de componentes cutâneos e cinestésicos, através dos quais impressões, sensações e vibrações detectadas pelo indivíduo são interpretadas pelo cérebro, sendo fontes valiosas de informação. Por isso, esse sistema é de suma importância para que a pessoa cega conheça o mundo. É pertinente esclarecer a diferença entre tato passivo e tato ativo, pois no caso do primeiro, a informação ocorre de forma casual, não intencional. Já no segundo, há a intenção de se buscar a informação. Esse é o que mais interessa no que se refere à Geografia, a exploração e o conhecimento do espaço, mesmo que seja por meio de caminhos perceptuais diferentes.

No ensino inclusivo da Geografia, desvendar o ambiente requer que a nossa percepção não só visual, mas auditiva, olfativa e, principalmente, tátil, consiga captar os elementos constitutivos do ambiente. Fazer uso dos sentidos e sensações para perceber e retratar esse ambiente traz uma 'nova' dimensão para a Geografia, passando a ser valorizada a partir da perspectiva humanística.

A localização dos fenômenos é um dos elementos do saber geográfico, assim, quando utilizamos a palavra "onde", sua resposta remete à Geografia. Além disso, as relações espaço-temporais e as relações sociais devem ser estudadas nas diversas escalas geográficas: local, regional, nacional e global. Esse processo reconhece que 
a percepção da paisagem vai além do que é visto, abrange a subjetividade humana, os sentimentos, os pensamentos e as emoções do ser histórico-social (SOUZA, ARAÚJO, 2015). Para tanto, essa discussão indica que

[...] a Geografia da Percepção preocupa-se em mostrar o mundo contemporâneo a partir da experiência vivida por cada um e seu nível de consciência, bem como suas ideias e sentimentos em relação ao espaço geográfico. Ela procura compreender o comportamento e as maneiras de sentir e agir das pessoas perante situações presentes no espaço vivenciado. (SEABRA, 2011, p. 81).

Os docentes podem trabalhar as categorias da Geografia com alunos com deficiência visual a partir dos mapas táteis e das maquetes, permitindo compreender e representar o ambiente o qual ele está inserido. O espaço geográfico sempre teve diferentes tipos de representações ao longo do pensamento geográfico. Pode ser representado por meio do globo, mapa, carta e planta. Por imagem é representado através do mosaico, da fotocarta, da ortofotocarta, da ortofotomapa, da fotoíndice e da carta imagem.

A cartografia é instrumento técnico de análise do espaço geográfico e a alfabetização geográfica perpassa pela percepção, visualização, codificação e decodificação dos símbolos, extraindo informações e interpretações espaciais. O princípio básico é baseado em Piaget e Inhelder (1993), ao afirmarem que a criança aprende agindo sobre o objeto, observando o espaço de sua vivência, do seu espaço empírico, que é uma realidade concreta. Mas, para ler os mapas, os leitores devem estar alfabetizados.

Na perspectiva da educação inclusiva, a cartografia tem um papel importante nesse processo e precisa fornecer materiais adequados para as pessoas com deficiência visual. Por isso, é preciso adaptar as representações gráficas para que possam ser percebidas pelo tato, oferecendo à pessoa com deficiência visual oportunidades semelhantes àqueles que podem ver (ALMEIDA, 2010).

Para potencializar o aprendizado dos alunos com deficiência visual, foi desenvolvido o sistema de leitura pela técnica de Braille, que constitui um avanço na inclusão de pessoas com deficiência visual. Nesse sentido, a cartografia se apoia na produção dos chamados mapas táteis para potencializar o processo de comunicação cartográfica. Entretanto, a eficácia da leitura depende da legibilidade dos símbolos, a confecção dos mapas, a habilidade e o conhecimento prévio do leitor (aluno com deficiência visual).

Portanto, a alfabetização cartográfica é uma vertente da geografia que precisa ser desenvolvida a fim de potencializar o entendimento do espaço geográfico dos alunos. No tocante à educação inclusiva, a linguagem cartográfica tátil é considerada um avanço, pois facilita a leitura e o entendimento dos elementos da geografia no ambiente em que os alunos com ou sem deficiência visual estão inseridos. (ALMEIDA, 2010; PASSINI, 2012).

\section{RESULTADOS E DISCUSSÕES}

O currículo do curso em que a aluna estava matriculada e que o auxílio das tecnologias assistivas foi necessário, incluiu as seguintes disciplinas: Geografia, Artes, Biologia, Contabilidade Básica, Economia e Finanças Pessoais, Educação Física, Empreendedorismo, Filosofia, Filosofia e Ética Empresarial, Finanças e Orçamento, Física, História, Introdução à Metodologia Científica, Informática, Língua Espanhola, 
Língua Inglesa, Língua Portuguesa, Matemática, Matemática Financeira, Noções de Antropologia, Noções de Direito e Legislação, Noções de Política, Processos Administrativos, Química, Recursos Humanos, Sociologia e Teoria das Organizações.

Observou-se, que apenas nas disciplinas do núcleo propedêutico foi solicitado o material adaptado à profissional de apoio especializado.

O conteúdo de Geografia, ministrado durante os três anos de curso, está detalhado no quadro 1. Para as temáticas que estão em destaque foram utilizados os materiais produzidos pela especialista, trabalhadas com as devidas adaptações e/ou utilização de outras linguagens, tal como a literatura.

Quadro 1 - Ementa da Disciplina Geografia no Curso Técnico em Administração Integrado ao Ensino Médio do IFTM ${ }^{4}$

$$
1^{\circ} \text { Ano }
$$

A relação homem-natureza e conceitos básicos da ciência geográfica. Localização e orientação no espaço. A representação do espaço geográfico. Mapas e seus elementos. Leitura e confecção de gráficos. Escala geográfica. Processo de desenvolvimento do modo de produção capitalista. Espaço e industrialização. Revolução Industrial. Noções de Geopolítica. O Pós-Segunda Guerra: Guerra Fria e a revolução técnico-científico-informacional. A nova Divisão Internacional do Trabalho. Globalização: redes e fluxos; Comunicação e transporte globais. Cidades globais. Fluxos migratórios mundiais. Comércio internacional: blocos econômicos. Desigualdades, consumo e meio ambiente. Globalização e conflitos no mundo contemporâneo.

\section{$2^{\circ}$ Ano}

Regionalização do mundo: a nova ordem mundial. União Europeia. Estados Unidos. Japão. China. Tigres Asiáticos. Países emergentes: G20. Geopolítica do Oriente Médio. Continente africano. Desigualdades globais. Estrutura geológica. Formação do Universo e do Sistema Solar. Formação do planeta Terra. Deriva continental e tectônica de placas. Estrutura geológica no Brasil. As formas do relevo. Classificações do relevo brasileiro. Agentes modificadores do relevo. Clima: elementos, fatores e conceitos. Mudanças climáticas e fenômenos climáticos. Pedologia. Formação e conservação do solo. Uso e ocupação do solo. Hidrografia: conceitos. Bacia hidrográfica. A dinâmica da hidrosfera: água continental e oceânica. Ciclo da água no planeta. Geopolítica da água: globalização, consumo e distribuição. Domínios morfoclimáticos.

\section{$3^{\circ}$ Ano}

Formação do território e do povo brasileiro. Regionalização e gestão do território brasileiro no século XX. Centro-Sul. Nordeste. Amazônia. Demografia: conceitos. Crescimento populacional no mundo e no Brasil. Análise de gráficos e pirâmides populacionais. Industrialização e urbanização no Brasil. Descentralização industrial. Indústria e produção de energia no Brasil. Fontes alternativas de energia. Urbanização e segregação espacial: favelização versus autossegregação.

\footnotetext{
${ }^{4}$ Disponível em: http://www.iftm.edu.br/patrocinio/cursos/tecnico-integrado-presencial/administracao/ppc/, que dispõem do Projeto Pedagógico do Curso Técnico em Administração Integrado ao Ensino Médio, IFTM, Campus Patrocínio-MG. Acesso em: 23 de jul. de 2019.
} 
Metrópoles. Conurbação. Problemas urbanos: violência, desemprego, moradia. Redes urbanas. Funções das cidades. $O$ crescimento urbano e os problemas ambientais. Plano diretor. Relações urbano-rural. Êxodo rural. Modernização da agricultura e a ocupação do Cerrado Brasileiro. Revolução Verde. Projetos de colonização. Estatuto da terra. Fronteiras agrícolas. Agronegócio versus campesinato. Movimentos sociais no campo e na cidade. Produção e produtividade agropecuária no Brasil e no mundo.

Fonte: adaptado do Projeto Pedagógico do Curso, 2014

Para a compensação da limitação causada pela cegueira, foi necessário produzir um material adaptado, que permitisse a independência da estudante quanto a sua manipulação, possibilitando assim, a compreensão satisfatória das temáticas do currículo.

O emprego da tecnologia assistiva durante as aulas buscou valorizar a utilização e estimulação do tato e da audição, que foi realizada através de explicações verbais da docente e dos colegas de classe. De acordo com os critérios préestabelecidos para elaborar os recursos didáticos que atendam às necessidades específicas da estudante em relação aos conteúdos de geografia, o material produzido foi composto por mapas táteis e maquetes.

\section{OS RECURSOS DIDÁTICOS NO ENSINO DA GEOGRAFIA INCLUSIVA: MAPAS TÁTEIS E MAQUETES}

Os mapas táteis são resultantes da transformação de mapas convencionais, impressos a tinta, em mapas com alto relevo, permitindo aos estudantes com deficiência visual a obtenção da informação acerca do objeto de estudo (ALMEIDA, 2010).

Para utilização desse material é necessário verificar, além do conhecimento prévio acerca da temática a ser trabalhada, se o aluno possui uma percepção tátil ativa para o reconhecimento das linhas, texturas, símbolos e orientação espacial daquilo que está sendo explorado. Caso contrário, deve-se proceder à alfabetização cartográfica tátil, de modo a minimizar as limitações.

Além de ter finalidade educativa na perspectiva do ensino da geografia, a cartografia tátil torna-se de grande utilidade, por facilitar a orientação e a mobilidade dos deficientes visuais nos seus espaços de vivência, permitindo um deslocamento de forma independente (RIBEIRO, 2012). Outro aspecto importante a ser considerado no reconhecimento de objetos ou na percepção do ambiente é se o aluno possui a memória visual.

A cegueira congênita é diferente da cegueira adquirida. Na primeira, o desenvolvimento psíquico, motor e cognitivo do sujeito ocorreu sem o auxílio do canal visual. A segunda, ocorreu durante o desenvolvimento do sujeito e como ele aprendeu a viver sem esse canal. Ambas as cegueiras dificultam muito a aprendizagem (FREITAS, VENTORINI, BORGES, 2018).

A estudante atendida, apesar de possuir uma memória visual, já que a perda de sua visão ocorreu durante a infância, não encontrou dificuldade no manuseio do material tátil, pois possui a alfabetização tátil e cartográfica, adquirida em escolarização anterior, possuindo também boa compreensão prévia dos conteúdos geográficos apresentados. 
A professora que elaborou o material específico relata que as principais dificuldades na produção dos materiais se associaram à falta de recursos financeiros para a compra dos insumos e a solicitação de adaptação/produção de materiais pelos professores com um curto prazo de tempo para entrega dos materiais.

Foram confeccionados mapas das seguintes temáticas: placas tectônicas; estrutura da Terra; perfis geomorfológicos do território brasileiro; teoria da deriva continental; biomas e formações vegetais; circulação geral da atmosfera (ventos regulares); tipos climáticos do Brasil; limites estaduais brasileiros, regiões brasileiras de acordo com o IBGE (norte, nordeste, sul, centro-oeste e sudeste); mesorregiões de Minas Gerais; projeções cartográficas (conforme, equivalente, equidistante e afilática), (Figuras 1, 2, 3 e 4). Além disso, a docente confeccionou um globo terrestre.

Figura 1. Mapa Tátil: placas tectônicas

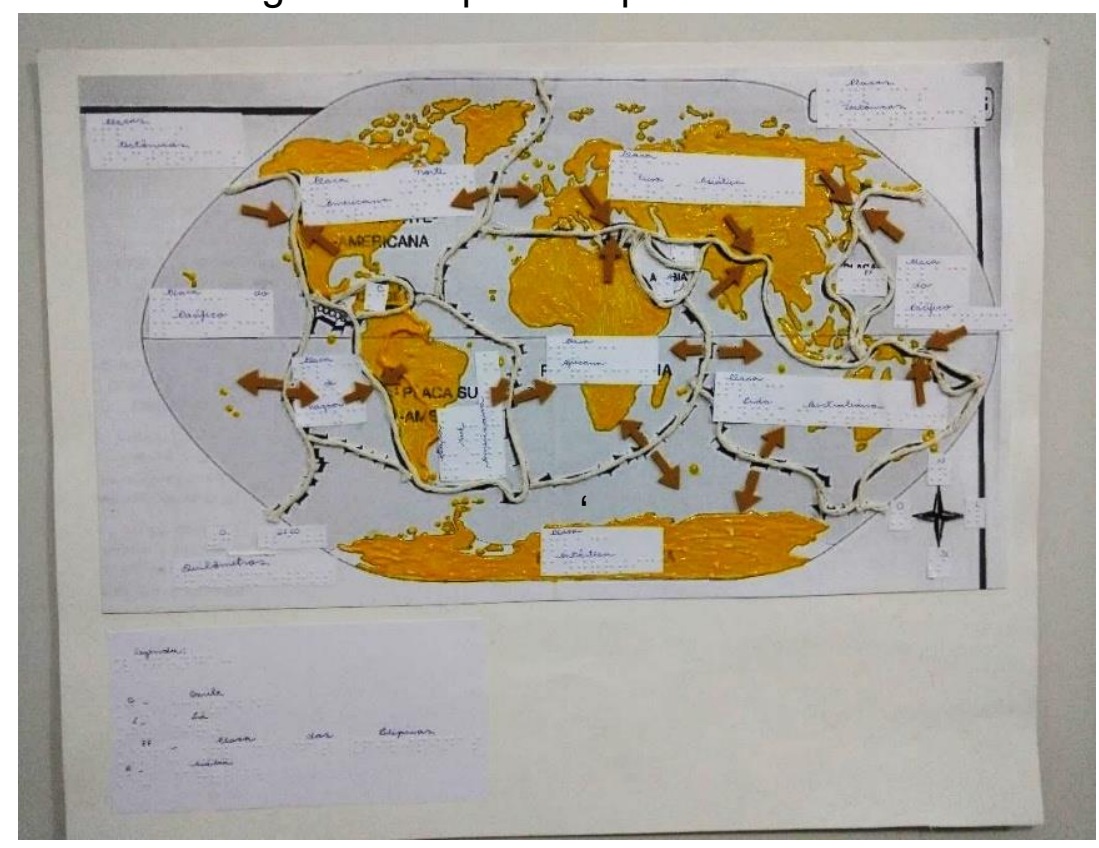

Fonte: registro da pesquisa

Figura 2 - Mapa Tátil: biomas e formações vegetais

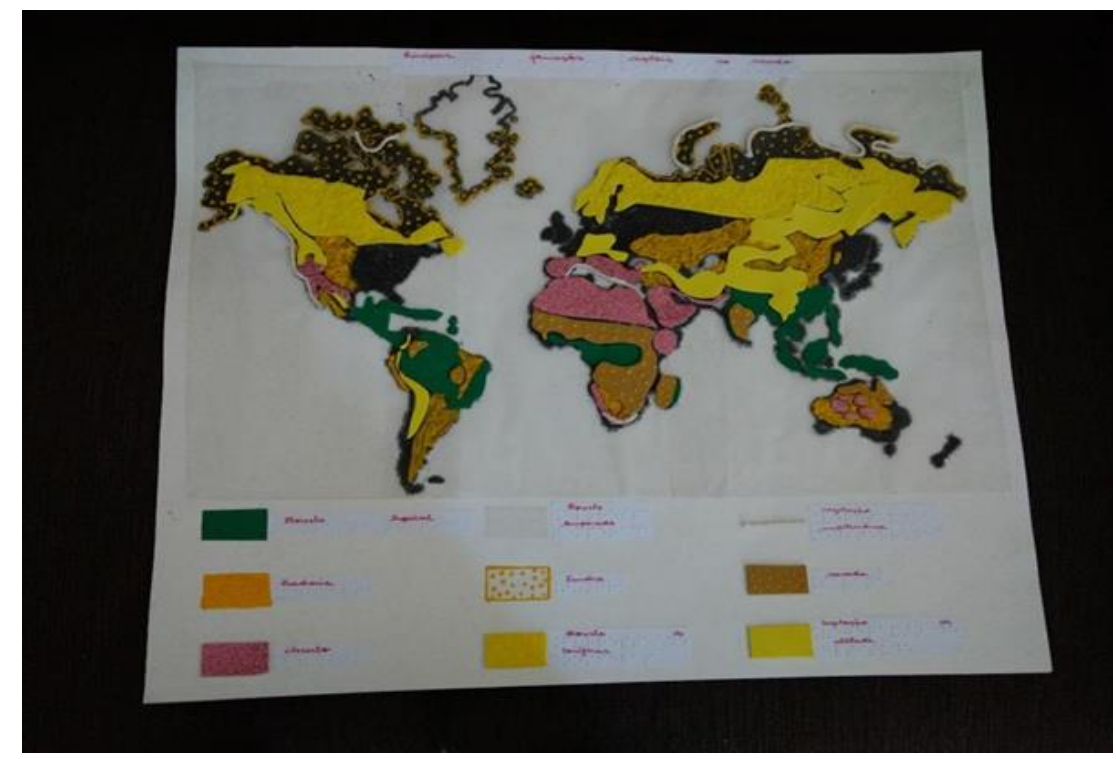

Fonte: registro da pesquisa 
Figura 3. Mapa Tátil: perfil geomorfológico das regiões norte, nordeste, centro-oeste e sudeste
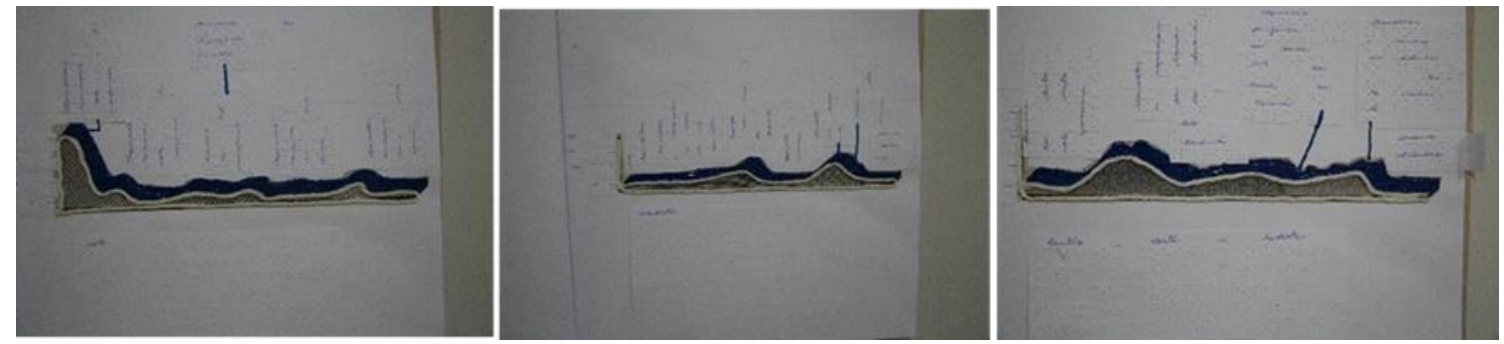

Fonte: registro da pesquisa

Figura 4. Mapa Tátil: circulação geral da atmosfera (ventos regulares)

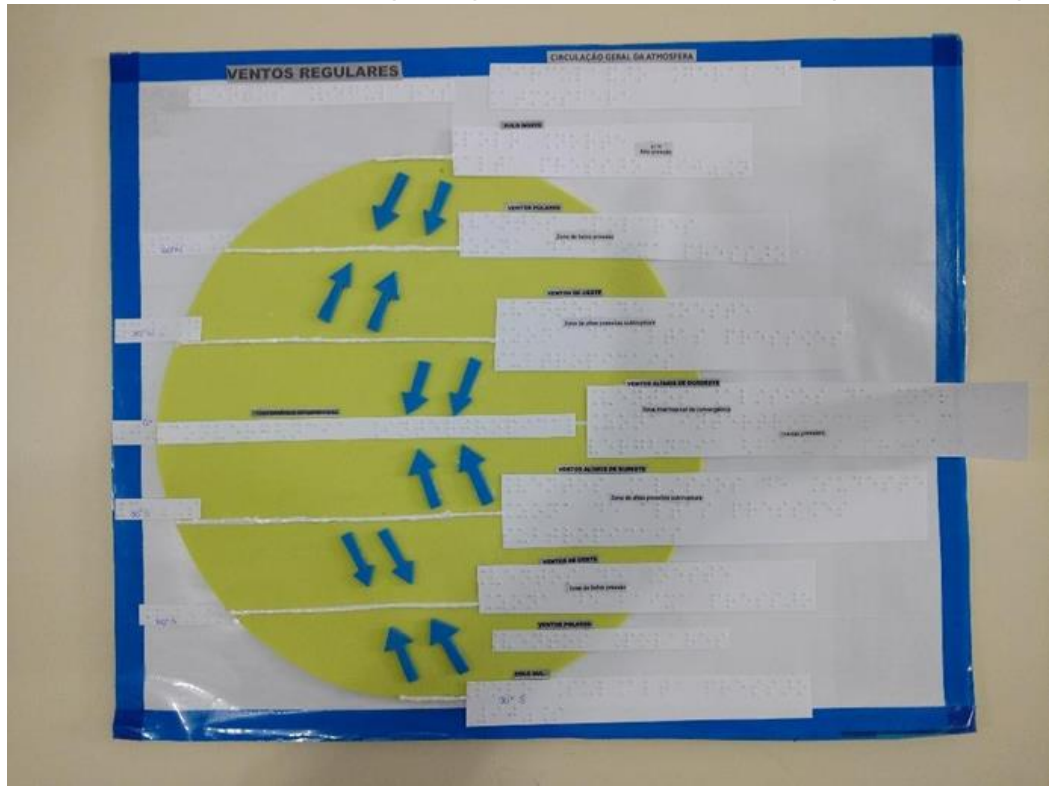

Fonte: registro da pesquisa

A confecção dos mapas começa pela sua conversão/aquisição em meio digital e sua impressão em papel tamanho A3. As informações são inseridas nos mapas táteis da seguinte maneira: as convenções cartográficas (título, escala, legenda, orientação, coordenadas) são escritas em pedaços de papel de forma convencional e em Braille, os quais são colados no mapa. O tema objeto do mapa é colocado em destaque em alto relevo, por meio da utilização de materiais como tinta, barbante, cola, grãos etc.

Os mapas foram utilizados durante a apresentação dos conteúdos em sala de aula, bem como durante os estudos realizados em casa, pela discente. Na exploração e leitura dos mapas, a aluna foi estimulada, com o auxílio da docente de Geografia, a identificar os fenômenos representados pelas diferentes texturas, além de alcançar a noção de proporção, redução, ampliação, representação dos signos, legendas e significados.

A utilização dos mapas em sala de aula alcançou os objetivos propostos. Entretanto, alguns deles ficaram incompletos em relação às convenções cartográficas, pois faltavam importantes elementos constitutivos de um mapa na base utilizada, como escala e orientação, o que só foi observado posteriormente. A confecção e utilização das maquetes seguiram essas proposições cartográficas.

A maquete é uma representação tridimensional do ambiente ou de um fenômeno, podendo conter informações escritas da forma convencional ou em Braille. 
Na perspectiva inclusiva, é um bom recurso didático para o aprendizado, não somente do aluno com deficiência visual, mas, também, para os demais integrantes da turma. Deve-se evitar que esse tipo de atividade seja solicitado apenas pelo seu teor lúdico ou artesanal.

No que se refere aos conteúdos de Geografia, o uso de imagens e maquetes é indispensável para que haja um melhor entendimento do conteúdo pelo aluno. A maneira que será ensinada, ou seja, o método de escolha do pedagogo, reflete sua maneira de pensar e interpretar o conteúdo, considerando suas experiências e práticas. Já o conteúdo a ser ensinado é o resultado de uma interação entre sujeito (professor) e objeto (conteúdo a ser lecionado), portanto, algo resultante da construção do sujeito (SUERTEGARAY, 2000).

As dificuldades encontradas ao se estudar os conteúdos que incluem as noções de planimetria e altimetria em uma carta topográfica, por exemplo, podem ser sanadas com a utilização desse recurso. Pode-se estimular também, a análise integrada da paisagem, a partir das discussões acerca do uso da terra, hidrografia, ação antrópica, constituição do solo, biomas etc. (CASTRO, 2018).

Para oportunizar uma inclusão efetiva, optou-se pela utilização desse recurso em sala de aula com fins avaliativos. Assim, diferentemente dos mapas táteis, confeccionados pela profissional de apoio, as maquetes foram confeccionadas pelos próprios discentes, de modo a proporcionar o processo de inclusão entre a aluna com deficiência visual e os demais alunos, buscando proporcionar melhor ensinoaprendizagem dos conteúdos geográficos.

Após a abordagem dos conteúdos lecionados no $2^{\circ}$ ano, em destaque no quadro 1, procedeu-se ao processo de verificação da aprendizagem por meio da avaliação, momento em que foi possível esclarecer para todos os sujeitos participantes do processo de ensino-aprendizagem (alunos e professor), se os objetivos pedagógicos foram atingidos. Para tanto, escolheu-se a realização de uma avaliação não convencional (classificatória, com questões discursivas), sendo de caráter formativo, estimulando e valorizando a participação ativa e a postura coletiva dos estudantes.

Assim, a turma foi dividida em pequenos grupos, de três ou quatro integrantes, que se encarregaram das diversas temáticas de estudo: deriva continental, placas tectônicas; estrutura da Terra, ciclo das rochas, tipos de rochas; estrutura geológica e formas de relevo; solos e biomas. Cada tema continha uma lista dos tópicos que poderiam ser abordados. Foi solicitado a cada grupo que apresentasse o conteúdo escolhido, de formal oral, e exemplificando o fenômeno por meio de um experimento prático ou utilização de maquete em sala de aula.

Os estudantes confeccionaram, em grupos, maquetes com a participação da discente com cegueira, que pôde, por meio da estimulação tátil nas maquetes e experimentos, interpretar o material produzido por eles, conforme as figuras 5, 6, 7, 8 e 9. A apresentação das convenções cartográficas (título, escala, legenda e orientação) foi considerada imprescindível nos materiais confeccionados a partir da transformação de uma representação bidimensional (mapa) para uma tridimensional (maquete). O grupo de alunos que não observaram as convenções cartográficas, foram orientados a inseri-las nas maquetes. 
Figura 5. Maquete: biomas brasileiros
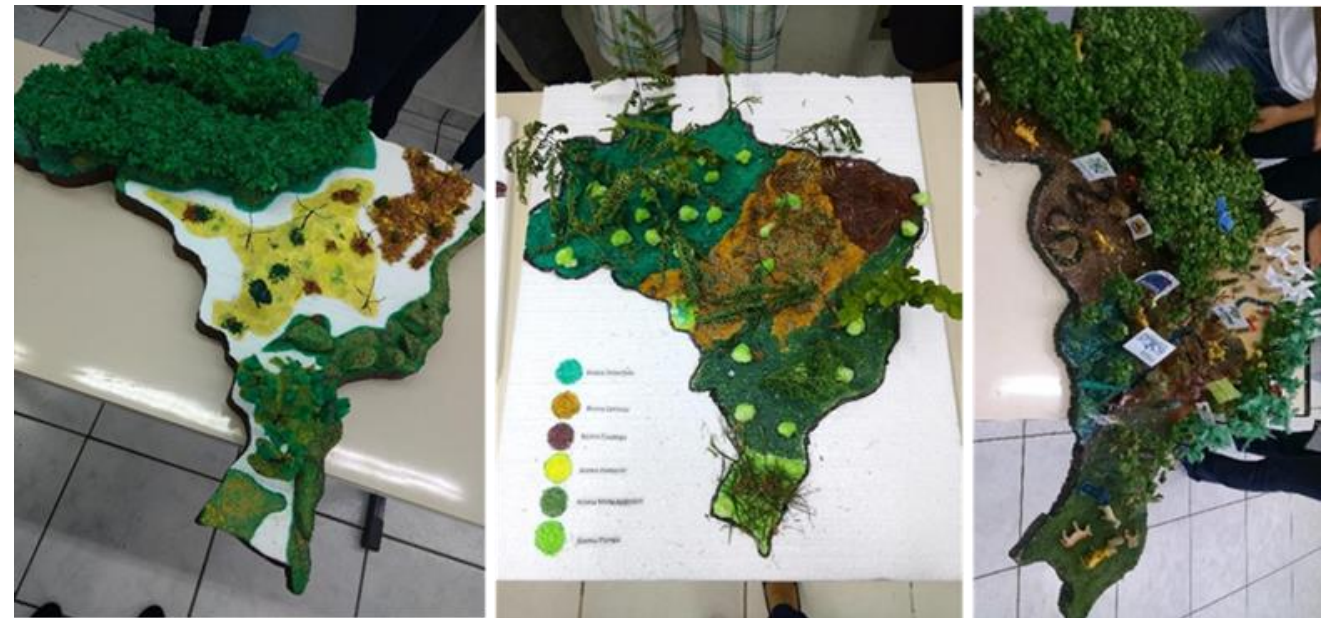

Fonte: registro da pesquisa

Dentre os experimentos escolhidos para apresentação dos grupos, foi realizada a simulação de erosão de encostas, mostrando a ação humana na natureza, a partir da ocupação das áreas de risco, comprometendo o equilíbrio ambiental. Foi realizada também uma simulação de ocorrência de terremotos, com a utilização de equipamentos eletrônicos para dar movimentação a maquete, variando de acordo com a magnitude de cada sismo apresentado.

Figura 6. Maquete: simulação de erosão nas encostas e terremoto

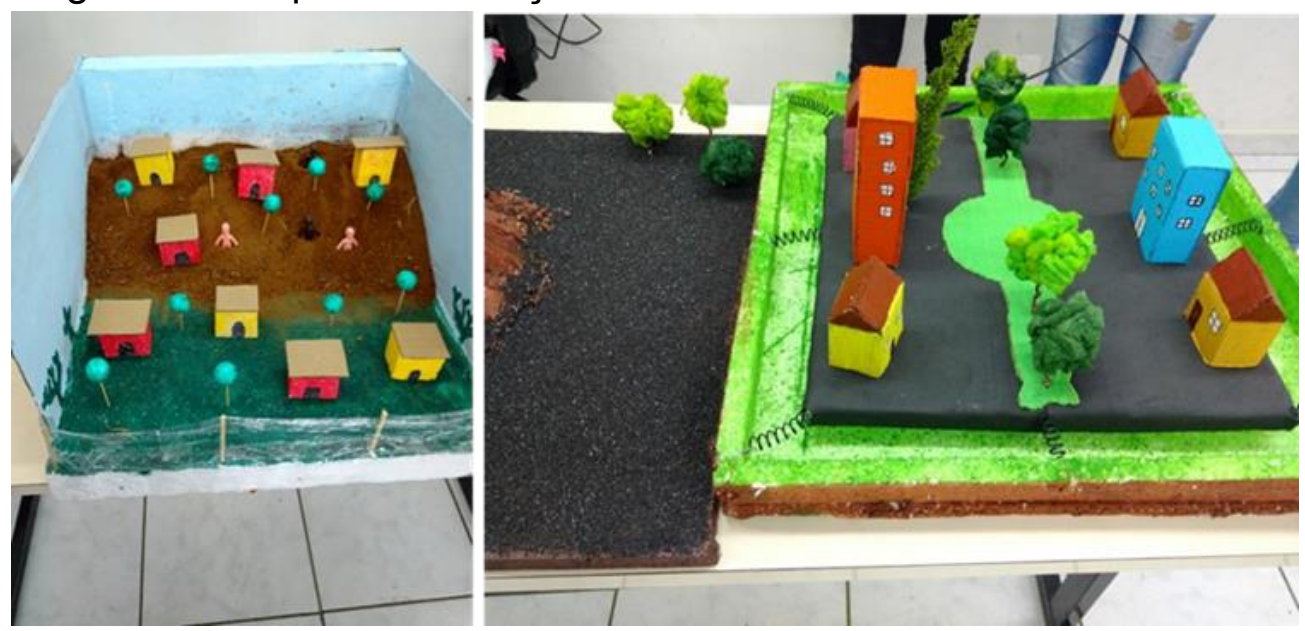

Fonte: registro da pesquisa 
Figura 7. Maquete: movimentos de placas tectônicas e estrutura da Terra

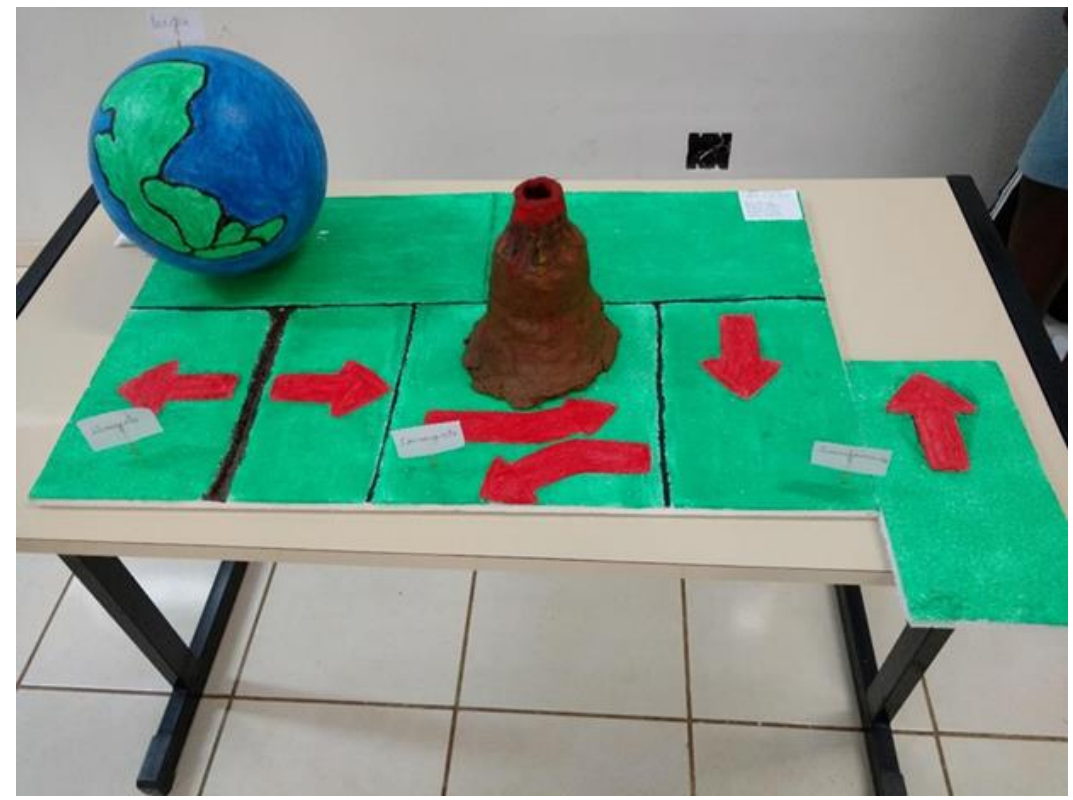

Fonte: registro da pesquisa

Figura 8. Experimento demonstrando a importância da vegetação no processo de erosão

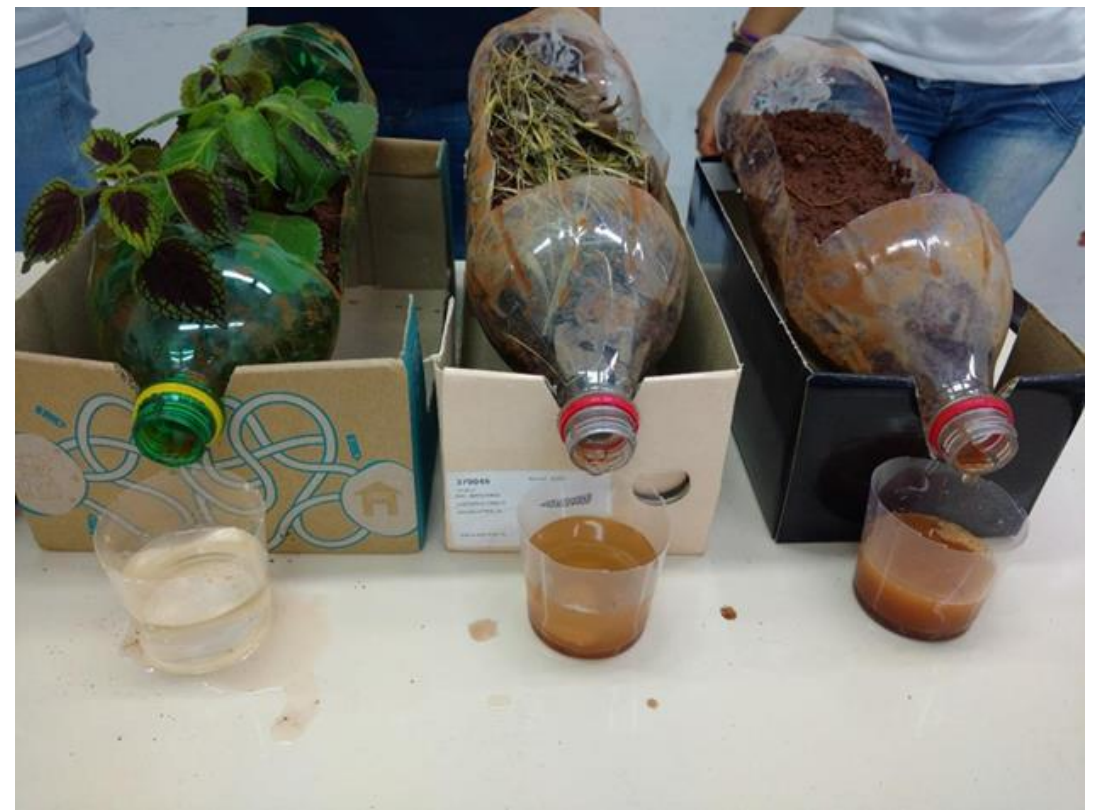

Fonte: registro da pesquisa 
Figura 9. Maquete: estrutura e formas de relevo

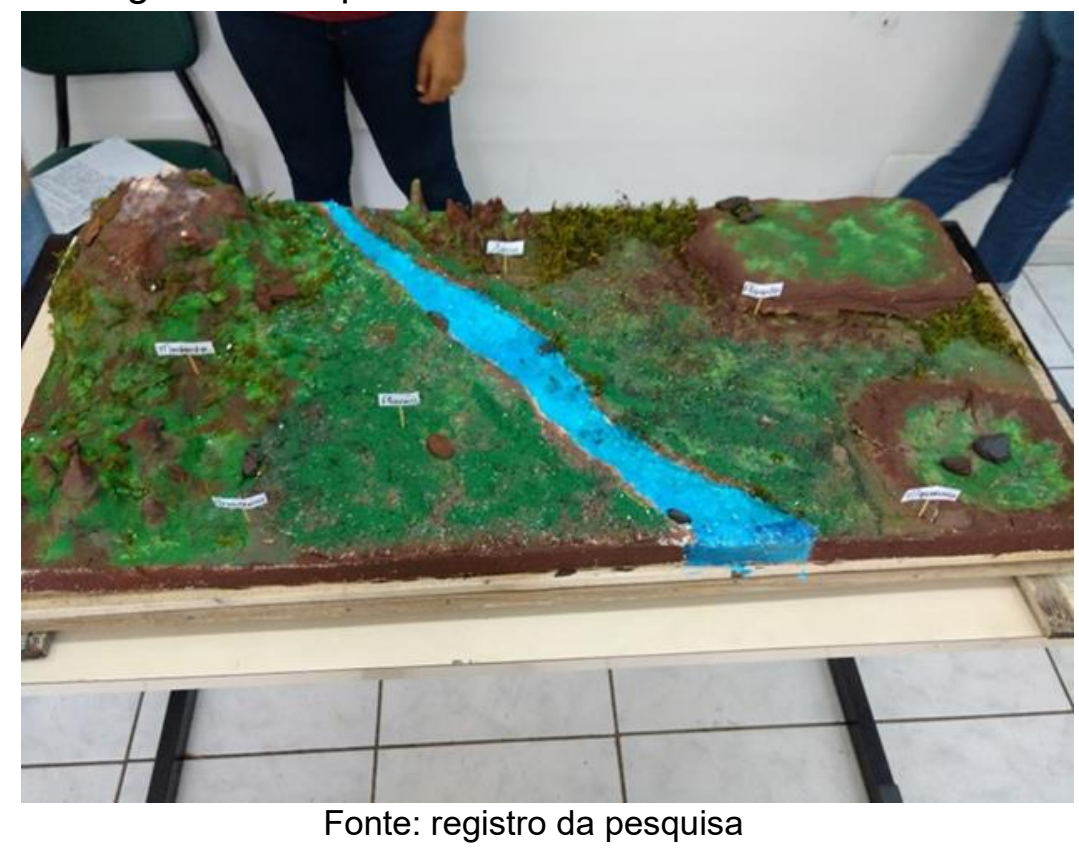

A estudante com deficiência visual relatou a contribuição que os materiais didáticos adaptados trouxeram durante o processo de aprendizagem das disciplinas a ela ofertada. No geral,

\begin{abstract}
os gráficos foram mais importantes em disciplinas como química, física e matemática, para que eu pudesse compreender melhor como se dão determinados fenômenos químicos e físicos e como se comportam as diferentes funções. Imagens e esquemas foram fundamentais no estudo da biologia, da história e da geografia, de forma que para as duas últimas, se mostraram ainda mais relevantes os mapas táteis, sejam eles do meu estado, país, continente ou do mundo, pois me permitiram ampliar meus conhecimentos de maneira muito significativa. (Estudante X, 2018).
\end{abstract}

Além dos materiais adaptados, a discente expõe que para estudar com maior facilidade fez uso constante do computador com leitor de tela para realizar anotações durante as aulas, os trabalhos propostos e atividades avaliativas; assim como pesquisar na Web em sites como o Google e YouTube. Cabe ressaltar, que materiais como: slides, textos, apostilas e livros são adaptados com letras maiores e enviados por e-mail.

Enfatiza ainda que as dificuldades ao se utilizar os materiais adaptados em Braille não se relacionam com a compreensão deles, mas sim com a obtenção destes, tendo em vista a morosidade da sua confecção. Além disso, há a dificuldade no seu armazenamento e transporte, pois trata-se de, na maioria das vezes, um material volumoso. Importante relatar que os estudantes do campus IFTM não possuem armários para armazenamento de seus pertences.

Desse modo, os demais esforços da estudante estão relacionados às saídas a campo e visitas técnicas. Ela relata que sempre contou com o apoio de professores ou colegas de turma para explicações e descrições, quando necessárias, para que pudesse participar ativamente das atividades propostas. Além das atividades de 
ensino, a discente concluiu com êxito um projeto de extensão e um projeto de pesquisa na referida instituição.

Após as apresentações, foi feita uma avaliação detalhada junto com os alunos, de modo que eles puderam ter um retorno sobre os seus desempenhos, tanto em relação à maquete quanto ao experimento apresentado, bem como as discussões sobre os processos pertinentes aos fenômenos abordados. A referida aluna, no processo de avaliações somativas, obteve destaque na turma, obtendo os melhores resultados.

Posteriormente a essa avaliação, em forma de maquetes e experimentos, os estudantes também realizaram a avaliação com questões dissertativas e de múltipla escolha, que também é considerada de suma importância, tendo em vista a preparação para o Exame Nacional do Ensino Médio (ENEM). Esta avaliação, ocorreu com o apoio pedagógico da profissional que adaptou todo o material em Braille para facilitar o entendimento da referida aluna.

\section{CONSIDERAÇÕES FINAIS}

É preciso repensar a Geografia Escolar na perspectiva inclusiva. A realidade encontrada na rede federal de ensino pesquisada, que ofereceu as condições mínimas necessárias para o atendimento das necessidades da estudante, ainda diverge daquela apresentada nas escolas públicas estaduais e municipais, onde se encontram $93,4 \%$ dos alunos deficientes matriculados no país, dificultando o trabalho docente e a aprendizagem dos alunos com deficiência visual (BRASIL, 2017).

Posto isso, o papel do professor é fundamental no êxito do ensinoaprendizagem. Exercer a sua função requer atualização constante, não somente das temáticas específicas dos conteúdos geográficos abordados, mas principalmente as temáticas acerca da Educação Inclusiva.

Um dos principais entraves para a efetivação da inclusão é o despreparo do docente, que não recebeu a formação necessária para trabalhar com o público-alvo da Educação Especial. A ausência de formação continuada, a falta de tempo para buscar qualificação e preparar materiais didáticos adaptados são outros impedimentos. Nesse sentindo, a parceria entre o professor da disciplina ministrada e o professor de apoio especializado é fundamental.

É essencial também que as instituições ofereçam diversos cursos que contemplem em seus currículos a prática na Educação Especial, quer seja no ensino, na pesquisa e/ou nas atividades de extensão. Ainda nessa perspectiva, os avanços de recursos tecnológicos devem estar presentes nessas instituições escolares.

A pesquisa foi desenvolvida no intuito de compreender como se dá o processo de ensino-aprendizagem em Geografia, para a estudante com deficiência visual. Para tanto, foram realizadas práticas pedagógicas que merecem ser difundidas e aprimoradas, a partir dos seus acertos e erros. O mapa tátil, as maquetes, experimentos e a interdisciplinaridade com a literatura, se mostraram tecnologias assistivas de destaque e proporcionaram qualidade no processo de ensinoaprendizagem da Geografia.

Diante do contexto, é importante, ainda, realizar adequações e confecção de outros materiais adaptados, pensados com maior rigor cartográfico e estético, a partir do que foi vivenciado, que buscou a aprendizagem geográfica da aluna com deficiência visual. Destaca-se que a compreensão do material adaptado não se dava de modo satisfatório em sala de aula, pois a discente buscava orientações junto a 
outros docentes para a elaboração dos materiais em Braille, em horários extracurriculares.

\section{REFERÊNCIAS BIBLIOGRÁFICAS}

ALMEIDA, Regina Araújo. A cartografia tátil no ensino de Geografia. In: ALMEIDA, Rosângela Doin de (org.). Cartografia escolar. 2. Ed. São Paulo: Contexto, 2010. p. 119-144.

ALMEIDA, Rosângela Doin de. Uma proposta metodológica para a compreensão de mapas geográficos. In: ALMEIDA, Rosângela Doin de (org.). Cartografia escolar. $2^{a}$ Ed. São Paulo: Contexto, 2010. p. 145-172.

ANSELMO, Rita de Cássia Martins de Souza. A formação do professor de geografia e o contexto da formação nacional brasileira. In: PONTUSCHKA, Nídia Nacib; OLIVEIRA, Ariovaldo Umbelino (orgs.). Geografia em perspectiva. ${ }^{a}$ Ed. São Paulo: Contexto, 2015. p. 247-254.

ALMEIDA, Rosângela Doin de; PASSINI, Elza Yasuko. O espaço geográfico: ensino e representação. $15^{\mathrm{a}}$ Ed. São Paulo: Contexto, 2010.

BERSCH, Rita; TONOLLI, José Carlos. Tecnologia Assistiva. 2006. Disponível em: http://www. assistiva. com.br/. Acesso em: 06 mai. 2018.

BRASIL. Constituição da República Federativa do Brasil. Brasília, DF: Presidência da República, $1988 . \quad$ Disponível em: www.planalto.gov.br/ccivil 03/constituicao/constituicao.htm. Acesso em: 06 abr. 2018.

BRASIL. Declaração de Salamanca e linha de ação sobre necessidades educativas especiais. Brasília: UNESCO, 1994. Disponível em: http://portal.mec.gov.br/seesp/arquivos/pdf/salamanca.pdf. Acesso em: 24 jul. 2018.

BRASIL. Ministério da Educação. Secretaria de Educação Especial. Política Nacional de Educação Especial. Brasília: MEC/SEESP, 1994. Disponível em: http://portal.mec.gov.br/index.php?option=com docman\&view=download\&alias=1669 0-politica-nacional-de-educacao-especial-na-perspectiva-da-educacao-inclusiva05122014\&ltemid=30192. Acesso em: 24 jul. 2018.

BRASIL. Lei n. ${ }^{\circ}$ 9.394, de 20 de dezembro de 1996. Estabelece as Leis de Diretrizes e Bases da Educação Nacional. Brasília, DF: Presidência da República, 1996. Disponível em: http://www.planalto.gov.br/ccivil 03/LEIS/L9394.htm. Acesso: 30 mar. 2018.

BRASIL, Lei $\mathbf{n}^{0} \mathbf{1 0 . 4 3 6}$, de 24 de abril de 2002. Dispõe sobre a Língua Brasileira de Sinais - Libras e dá outras providências. Brasília, DF: Presidência da República, 2002. Disponível em: http://www.planalto.gov.br/ccivil 03/leis/2002//10436.htm. Acesso em: 15 set. 2018.

BRASIL. Política Nacional de Educação Especial na Perspectiva da Educação Inclusiva. Brasília: MEC/SEESP, 2008. 
BRASIL. Instituto Nacional de Estudos e Pesquisas Educacionais Anísio Teixeira (INEP). Censo Escolar 2017. Disponível em: http://portal.inep.gov.br/censo-escolar. Acesso: 20 set. 2018.

BRASIL. Decreto n. ${ }^{\circ}$ 7.611, de 17 de novembro de 2011. Política Nacional de Educação Especial. Disponível em: http://www.planalto.gov.br/ccivil 03/ Ato20112014/2011/Decreto/D7611.htm. Acesso em: 15 set. 2018.

BRASIL. Lei n. ${ }^{13.146}$, de 6 de julho de 2015. Lei Brasileira de Inclusão da Pessoa com Deficiência (Estatuto da Pessoa com Deficiência). Disponível em: http://www.planalto.gov.br/ccivil 03/ ato2015-2018/2015/lei/l13146.htm. Acesso em: 15 set. 2018.

CASTRO, José Flávio Morais. História da Cartografia e Cartografia Sistemática. $2^{a}$ Ed. Belo Horizonte: Editora PUC Minas, 2018.

FREITAS, Maria Isabel de; VENTORINI, Sílvia Elena; BORGES, José Antônio. Maquetes Táteis, Dispositivos Sonoros e Aula Inclusivas. In: ALMEIDA, Rosângela Doin de (org.). Novos Rumos da Cartografia Escolar. São Paulo: Contexto, 2018. p. 109-120.

GEERTZ, Clifford. A interpretação das culturas. Rio de Janeiro: LTC, 2008.

LENCIONI, Sandra. Região e geografia. São Paulo: EDUSP, 2003.

MANTOAN. Maria Teresa Eglér. Inclusão escolar: o que é? por quê? como fazer? São Paulo: Moderna, 2003.

PASSINI, Elza Yasuko. Alfabetização cartográfica e a aprendizagem de geografia. $1^{\text {a }}$ Ed. São Paulo: Cortez, 2012.

PENNA, Antonio Gomes. Percepção e realidade: introdução ao estudo da atividade perceptiva. Rio de Janeiro: Mercúrio Star, 1982.

PIAGET, Jean; INHELDER, B. A representação do espaço na criança. Porto Alegre: Artes Médicas, 1993.

RIBEIRO, Solange Lucas. A Interface Educação Geográfica e Inclusão de Alunos com Deficiência Visual: possíveis contribuições para representar e desvendar o espaço. In: PORTUGAL, Jussara Fraga; CHAIGAR, Vânia Alves Martins (Orgs.). Cartografia, Cinema, Literatura e Outras Linguagens no Ensino de Geografia. Curitiba: Editora CRV, 2012. p. 91-108.

RODRIGUES, Leandro. 10 fatos da História da Educação Especial que você precisa saber! Instituto Itard. 2017. Disponível em: http://institutoitard.com.br/10fatos-da-historia-da-educacao-especial-que-voce-precisa-saber/. Acesso: $18 \mathrm{mar}$. 2018. 
ROPOLI, Edilene Aparecida et al. A Educação Especial na Perspectiva da Inclusão Escolar: a escola comum inclusiva. Brasília: Ministério da Educação, Secretaria de Educação Especial; (Fortaleza): Universidade Federal do Ceará, 2010.

SASSAKI, Romeu Kazumi. Inclusão: acessibilidade no lazer, trabalho e educação. Revista Nacional de Reabilitação (Reação). São Paulo, Ano XII, mar./abr. 2009, p. 10-16. Disponível em: https://acessibilidade.ufg.br/up/211/o/SASSAKI Acessibilidade.pdf?1473203319. Acesso em: 15 ago. 2019.

SEABRA, Giovanni. Geografia: fundamentos e perspectivas. $4^{a}$ edição. João Pessoa/PB: Editora Universitária/UFPB, 2007.

SOUZA, Álvaro José de. A formação do professor de geografia. In: PONTUSCHKA, Nídia Nacib; OLIVEIRA, Ariovaldo Umbelino (Orgs.). Geografia em perspectiva. $4^{\text {a }}$ Ed. São Paulo: Contexto, 2015. p. 261-266.

SOUZA, Francisco Alan Martins de; ARAUJO, Karlane Holanda. Práticas Educacionais para Trabalhar o Conceito de Paisagem Geográfica com Alunos do $6^{\circ}$ Ano do Ensino Fundamental do Instituto de Cegos do Ceará. Anais da XXII Semana de Educação da Universidade Estadual do Ceará. 2015. Disponível em: http://www.uece.br/eventos/semanadeeducacaouece/anais/resumos/9238.html.

Acesso em: 23 fev. 2019.

SUERTEGARAY, D. M. A. Espaço geográfico: uno e múltiplo. In: SUERTEGARAY, D. M. A.; BASSO, A.; VERDUM, R. (Orgs.). Ambiente e lugar no urbano: a Grande Porto Alegre. Porto Alegre: Ed. da UFRGS, 2000. p. 13-34.

TRIVIÑOS, Augusto Nibaldo Silva. Introdução à pesquisa em ciências sociais: pesquisa qualitativa em educação. São Paulo: Atlas, 1987.

TUAN, Y-F. Topofilia: um estudo da percepção, atitudes e valores do meio ambiente. Londrina: EDUEL, 2012.

VESENTINI, José Willian. A formação do professor de geografia: algumas reflexões. In: PONTUSCHKA, Nídia Nacib; OLIVEIRA, Ariovaldo Umbelino (Orgs.). Geografia em perspectiva. $4^{\text {a }}$ Ed. São Paulo: Contexto, 2015. p. 235-240. 